\title{
ПОЧАТKОВА ОСВITA
}

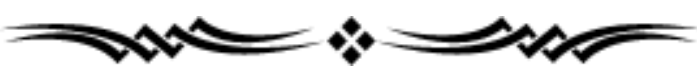

DOI $10.31651 / 2524-2660-2020-2-238-242$

ORCID 0000-0003-2059-3686

\section{КОНДРАТЬСВА Аһъона Васимівна,}

кандидатка філософських наук, доцентка кафедри дошкільної та початкової освіти, Комунальний заклад вищої освіти "Дніпровська академія неперервної освіти"

Дніпропетровської обласної ради

e-mail: k.alena_11.12@ukr.net

УДК 373.3.091.2:005.336.2(045)

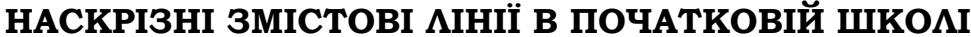

У статті розглянуто поняття і сутність наскрізних змістових ліній. Розкрито особливості впровадження наскрізних змістових ліній в початковій школі. Зазначено, шо проиес навчання й соиіалізаиї учнів початкової школи завдяки впровадженню наскрізних змістових ліній буде оптимальним на основі використання комунікативного та особистісно оріентованого навчання, активних та інтерактивних технологій $і$ методів навчання, навчальної проектної діяльності.

КАючові слова: нова украйнсъка школа; комунікативне навчання; особистісно орієнтоване навчання соиіалізаиія особистості; початкова освіта; навчання, учень; навчальна програма; наскрізні змістові лінії; компетентності.

Постановка пробцеми. За роки незамежності Української держави система національної початкової освіти зазнала суттєвих змін: напрацьовано підходи до розвитку та вдосконалення початкової освіти не мише як обов'язкової структурної складової освіти, а й як початкової базової манки в системі загальної безперервної освіти особистості. Нормативно-правові документи в освітній сфері визначають нові підходи до виховання та навчання дітей, висувають завдання гармонійного, цілісного розвитку підростаючого покоління із сформованими компетенціями.

Державний стандарт базової і повної загальної середньої освіти [1] визначив її кАючові завдання, до яких відносять: формування в учнів громадянської відповідамьності, духовності й культури, самостійності, ініціативності, толерантності, здатності до адаптації та соціалізації. Відповідно до Державного стандарту початкової освіти, метою початкової школи є "всебічний розвиток дитини, iї талантів, здібностей, компетентностей та наскрізних умінь відповідно до вікових та індивідуальних психофізіологічних особливостей і потреб, формування цінностей, розвиток самостійності, творчості та допитмивості" [2].

Сучасні вимоги до початкової освіти актуалізують пробцему особистісно орієнто- ваних технологій педагогіки, розглядаючи ï як засіб формування особистості, здатної мобільно реагувати на виклики часу, орієнтуватися в мінливих соціальних ситуаціях. При цьому основні акценти ставцяться на інтелектуальному і моральному розвитку особистості як носія культурного та історичного досвіду.

Компетентнісний підхід у навчанні та особистісно орієнтовані технології були й залишається предметом вивчення численних наукових досліджень вітчизняних та зарубіжних науковців (Н. Бібік, О. Овчарук, О. Пометун, О. Савченко, В. Краєвський, О. Крисан, Д. Равен, А. Хуторський та ін.). Однак сьогодні ще мало розробок в напрямі впровадження в початкову освіту наскрізних змістових міній як дієвого засобу інтеграції ключових і загальнопредметних компетентностей, навчальних предметів та предметних циклів початкової освіти.

Метою статті $є$ дослідження поняття i сутності наскрізних змістових міній; вивчення особливостей впровадження наскрізних змістових міній в початковій шко$\Lambda$ i.

Дия розв'язання поставленої мети використано комплекс теоретичних методів, зумовлених специфікою проблеми: аналіз психолого-педагогічної, методичної мітератури з метою уточнення сутності базових понять дослідження; аналіз державних документів, спрямованих на врегулювання процесу освіти в Україні, чинних навчальних планів, програм, підручників і посібників для учнів початкової школи

Виклад основного матеріалу. Орієнтація навчально-виховного процесу на особистість як найвищу цінність вимагає переосмислення традиційних форм і методів педагогічного впииву, пошуку нових, ефективних прийомів організації особистісноорієнтованої навчально-виховної взаємодії педагога i учнів. Одним із стратегічних напрямків реформування початкової освіти в Україні є гуманістична спрямованість 
педагогічного процесу, що грунтується на засадах гмибокої поваги до особистості учня, врахування особливостей його індивідуального розвитку, створенні особливого психологічно комфортного навчального середовища в закладі освіти. Застосування компетентнісного підходу, реалізація інтегрованих змістових міній за сучасними підручниками дмя початкової школи із використанням ефективних технологій забезпечує можливість сформувати належний рівень навчальних досягнень молодших шкомярів, актуалізувати їх пізнавальну активність та соціалізувати їх [3].

Сьогодні мета початкової школи полягає в навчанні й вихованні різнобічно розвиненої та соціально активної особистості, яка розуміє вимоги часу, має сформовані якості й цінності, які дозволять їй успішно адаптуватися в новому соціальному та інформаційному просторі та $є$ необхідними у практичній діяльності.

В основі навчання молодших школярів взаємодія учнів та вчителя - навчання, пізнання, гра, спільна праця, спілкування. Поступово учень стає активним учасником навчально-виховного процесу. Він спільно 3 вчителем визначає мету, оволодіває новими знаннями, засвоює навчальні дії, експериментує, несе відповідальність за виконану роботу; він активно живе повноцінним життям, оскільки школа охоплює значний період життя кожної дитини. Найважливішим результатом початкової освіти в особистісному вимірі $€$ соціально активно, здорова дитина, зі сформованим мотивом до успішного навчання, дослідницьким ставценням до навколишнього світу; це учень, який уміє здобувати знання за допомогою різних джерел, здатен критично осмислювати інформацію, відповідально ставиться до себе та оточуючих, на практиці застосовує набуті знання, досвід, вміє відстояти вцасну позицію та реалізує вцасні ідеї, успішно адаптується у соціумі.

Учитель початкової школи, не порушуючи могіки вивчення того чи іншого предмета, передбаченого Державним стандартом шкільної програми, може наповнити новим соціально спрямованим змістом й інші теми, а також, використовуючи комплекс ефективних методів та засобів навчання, впливає на оволодіння молодшими школярами соціальною та соціокультурною компетентностями. Крім того, у змісті навчамьних програм початкової школи інтегровано компетентнісний підхід, що відповідає стратегічному напрямку розвитку освіти в межах приписів Концепції Нової української школи.

Під компетентнісним (діяльнісноорієнтованим) підходом в освіті ми розумі- ємо вдосконалення всієї освітньої системи, спрямоване на освоєння учнями соціокуль-

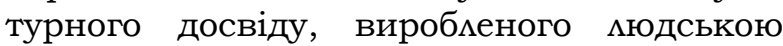
цивілізацією. Основною освітньою метою сучасної школи з позиції компетентнісного підходу $є$ формування у школярів ключових компетенцій, що дозволяють молодшому школяреві вирішувати завдання соціамьної комунікації. Зміст освіти в рамках компетентнісного підходу визначається чотирма компонентами: знаннями, вміннями, досвідом діяльності та досвідом ціннісного ставцення.

Новий стандарт початкової освіти акцентує увагу на тому, що компетентності, які закладаються в молодших класах, є наскрізними, а оволодіння ними може відбуватися через всі освітні області. Це означає, що, наприклад, мовної компетентності молодші школярі навчаються не тільки на уроці рідної мови або читання, як було раніше, а й на уроках мистецтва, де педагог може так само звертати увагу на мову учня. Це означає, що педагог може розподімити навантаження, побудувати свою стратегію навчання через ігрові моменти.

ВкАючення наскрізних тем у той чи інший предмет навчання в початковій шкомі $\epsilon$ однією з рис оновлених програм, що, в свою чергу, є засобом інтеграції предметів, роздіків, тем для реалізації міжпредметних зв'язків. Наскрізні теми органічно впцетені у зміст всіх предметів і в систему довгострокового та середньострокового планування. Тому при підготовці короткострокового плану вчителю необхідно дотримуватися системи наскрізних тем і враховувати ïx при складанні завдань і організації дія$\Lambda$ ьності учнів на уроці.

За рахунок реалізації в початкових клаcax наскрізних тем вирішуються питання реалізації тримовної освіти, яка передбачає навчання не тільки трьом мовам, але і організацію позаурочної діяльності учнів на трьох мовах (українською, англійською та третьою на вибір). Так, наприклад, загальна наскрізна тема з усіх навчальних предметів дає можливість відібрати мексичну предметну групу слів, що вивчається на уроках. При цьому учні матимуть можливість вивчити дану предметну групу слів i використовувати іiі у висловлюванні на трьох мовах, відповідно до мови навчання.

Педагог, який починає викладати предмети в початковій школі, стикається з масою проблем і питань: відбір змісту навчання, вибір навчально-методичного комплексу (HMK) та програмного забезпечення, вибір раціональних форм роботи на уроці, особливості викладання окремих тем предмету, організація ігор на уроках та ін. 
Згідно нового Державного стандарту шкільна програма $з$ предмету "Я досліджую світ" містить низку тем і питань, які безпосередньо пов'язані із проблемою соціалізації особистості, iї адаптації у соціумі [4]. Наприклад, особливостями змісту означеного навчального предмета $є$ : інтегрований характер подання природничо-наукових $\mathrm{i}$ суспільствознавчих знань, особлива увага до розширення чуттевого досвіду і практичної діяльності школярів, наявність змісту, що забезпечує формування загальних навчальних умінь, навичок і способів діяльності; можливість здійснювати міжпредметні зв'язки з іншими навчальними предметами початкової школи. Навчальний предмет "Я досліджую світ" вносить істотний внесок у формування інформаційної кумьтури молодших школярів; вони освоюють різні способи отримання інформації, використовують алгоритми, моделі, схеми та ін.

Основні змістові $\Lambda$ нії "Я досліджую світ" визначено стандартом початкової загальної освіти і представлені в приблизною програмі розділами: "Шо таке навколишній світ", "Молодший школяр", "Природа", "Аюдина і природа", "Суспільство", "Рідний край - мала Батьківщина", "Земля - планета життя". Вивчення навколишнього світу в початковій школі спрямоване на досягнення наступних цілей:

- розвиток умінь спостерігати, аналізувати, узагальнювати, характеризувати об'єкти навколишнього світу, міркувати, вирішувати творчі завдання;

- освоєння знань про навколишній світ, встановлення єдності і відмінності природного і соціального; про Аюдину та її місце в природі і суспільстві;

- виховання позитивного емоційноціннісного ставцення до навколишнього світу; екологічної та духовної культури, патріотичних почуттів; формування потреби брати участь у творчій діяльності в природі і суспільстві, зберігати і зміцнювати здоров'я.

Таким чином, у навчальних програмах зустрічаємо відносно нове поняття "наскрізні змістові мінії. Наскрізні змістові мінії є засобом інтеграції ключових і загаАьнопредметних компетентностей, які формуються у процесі вивчення навчальних предметів та предметних циклів. Наскрізні мінії слід розглядати як "соціально значимі надпредметні теми, що сприяють формуванню в учнів уявлення про суспільство в цілому - розвивають здатність застосовувати отримані знання у різних ситуаціях" [5].

САід погодитися з думкою В. Комлягіної стосовно того, що наскрізні змістові $\Lambda$ інії виступають "соціально значимими надпредметними темами, які допомагають формуванню в учнів уявлень про суспільство в цілому, розвивають здатність застосовувати отримані знання в різних ситуаціях", а їхньою метою $є$ забезпечення "розвитку ключових компетентностей, які є важливими для учня та для суспільства" [5].

Під наскрізними змістовими мініями в освітніх документах Нової української школи розуміють "соціально значущі надпредметні теми, що сприяють формуванню в учнів уявцення про суспільство в цілому, розвивають їню здатність застосовувати отримані знання у різних ситуаціях" [6]. Такі цінії є спільними дмя всіх навчальних предметів, вони слугують засобом інтеграції навчального змісту [6, с. 17-18]. Наскрізні змістові Аінії корелюються з основними компетентностями, сприяючи формуванню в учня ціннісних та світоглядних орієнтацій. Поєднуючи декілька навчальних завдань різних предметів початкової школи, наскрізні змістові Аінії зосереджують увагу й зусимяя педагогічного колективу на досягненні мети, яка є життєво важАивою для кожного школяра й суспільства загалом. Реалізація наскрізних змістових міній передбачає розв'язування завдань реального змісту; втілення міжпредметних навчальних проектів; пошукову діяльність 3 різними джерелами інформації тощо. Поняття "наскрізні мінії" запроваджене дмя того, щоб виокремити кАючові компетентності Нової української школи.

За твердженням В. Комлягіною, втілення наскрізних змістових міній програм у вивченні навчальних предметів на практиці дозволяє вирішити низку важливих завдань:

- розв'язувати завдання реального змісту;

- виконувати міжпредметні навчальні проекти;

- працювати 3 різними джерелами інформації [5].

Початкова освіта повинна формувати в молодших школярів наскрізні вміння: читання з розумінням, вміння висловлювати власну думку усно і письмово, критичне i системне мислення, здатність цогічно обгрунтовувати позицію, творчість, ініціативність, вміння конструктивно керувати емоціями, оцінювати ризики, приймати рішення, вирішувати проблеми, здатність співпрацювати з іншими. Наскрізні вміння служать підставою дмя інтеграції освітніх галузей. Дмя прикладу, у новій програмі з математики започатковано змістову Аінію 
"робота з даними", яка є наскрізною, і втімюється в усіх інших змістових мініях програми; сформульовано у компетентністних категоріях: "знає", "розуміє", "володіє", "аналізує", "застосовує", "перевіряє" та ін., вимоги до рівня навчальних досягнень учнів; не визначено чіткої послідовності вивчення учнями окремих змістових міній, тем і підтем, що забезпечує варіативність; дає можливість розширювати зміст навчання за допомогою додаткових питань програми [7, с. 287]. Тобто скрізні мінії слугують інтеграції основних і загальнопредметних компетентностей, а тому їх слід враховувати при формуванні навчальноосвітнього середовища.

Наскрізні змістові мінії - соціально значимі надпредметні теми, які допомагають молодшим школярам осмислити основні суспільні процеси, сформувати уявлення про суспільство в цікому, розвинути здатність застосовувати набуті знання у різних життєвих ситуаціях. Метою наскрізних змістових міній $є$ акцентуація уваги й зусимь педагогів на досягненні життєво важмивої для учня початкової школи й суспільства мети, увиразнити ключові компетентності.

ДАя наскрізної мінії "Я досліджую світ" це формування в молодших школярів соціальної активності, відповідальності й екомогічної свідомості, у результаті яких вони відповідально й дбайливо ставитимуться до живої і неживої природи, усвідомлюючи важливість природозбереження для розвитку суспільства. Ця наскрізна мінія втілюється як через індивідуамьну, так і колективну діяльність (дослідницькі роботи, роботи в групі, проекти тощо), які вчать шкомярів діяти самостійно і розвивають в них готовність до взаємодії, толерантність щодо різних думок і способів діяльності [8].

Метою вивчення наскрізної мінії "Фізична культура" $є$ формування фізично розвиненої особистості, здатної реалізувати творчий потенціал, активно використовувати фізичну культуру для зміцнення i збереження власного здоров'я, усвідомленого прийняття здоров'язбережувальних техномогій, захисту від несприятмивих природних і соціальних факторів [9, с. 45].

Як слушно зауважує О. Һюбченко, наскрізні змістові мінії спільні дия всіх начацьних предметів, іє засобом інтеграції навчальних предметів, предметних циклів i навчального змісту. Вони співвідносяться 3 окремими кАючовими компетентностями та сприяють формуванню цінностей і світогляду учня. Їх потрібно брати до уваги при формуванні освітнього середовища.
Впровадження у навчальний предмет наскрізних змістових міній передбачає розв'язування завдань реального змісту, виконання міжпредметних навчальних проектів, роботу з різними джерелами інформації [10]. Важливість інтеграції змістових міній не тягне за собою певних кардинальних змін у навчально-виховному процесі початкової школи, а передбачає мише зміщення акцентів на більш прикладні аспекти теми уроку.

ДАя підвищення рівнів сформованості ціннісно-смислових компетенцій молодших школярів необхідно дотримуватися таких педагогічних умов: реалізація принципу надмірності дия забезпечення свободи вибору учнями змісту, форм, методів колективної діяльності; міждисциплінарних проектів дия ефективного розвитку творчої пошукової активності учнів початкових класів. В цьому напрямку має будуватися навчальна і виховна діяльність всіх вчитемів початкової школи.

Висновки. Метою початкової освіти в сучасних умовах визначено всебічний розвиток особистості дитини відповідно до іiі вікових та індивідуальних психофізіологічних особливостей і пізнавальних потреб, формування загальнокультурних і морально-етичних цінностей, оволодіння кАючовими і предметними компетенціями і наскрізними вміннями, необхідними життєвими і соціальними навичками, які забезпечують їі готовність до життя в демократичному та інформаційному суспільстві і продовження навчання в основній школі. Досягненню означеної мети служать наскрізні змістовні мінії в початковій школі, які передбачають освоєння дітьми молодших класів соціально значимими надпредметними темами, що сприяють формуванню в них поняття про суспільство в цілому, розвивають здатність застосовувати здобуті знання на практиці. Наскрізні змістовні мінії є дієвим засобом інтеграції основних i загальнопредметних компетентностей, навчальних предметів та предметних циклів в початковій освіті.

\section{Список бібціографічних посимань}

1. Про затвердження Державного стандарту базової і повної загальної середньої освіти : Постанова КМ України №1392 від 23 кистопада 2011 року. URL: https://osvita.ua/legislation/Ser_osv/28030/.

2. Про затвердження Державного стандарту початкової освіти : Постанова КМ України № 87 від 21 Аютого 2018 року. URL: https://osvita.ua/legislation/Ser_osv/59891/.

3. Щодо методичних рекомендацій про викладання навчальних предметів у закладах загальної середньої освіти у 2019/2020 навчальному році : Аист MOH України № 1/11-5966 від 01.07.2019 p. URL: https://osvita.ua/legislation/Ser_osv/65024/. 
4. Про затвердження типових освітніх програм дия 1-2 кц. закладів загальної середньої освіти : наказ Міністерства освіти і науки України №1272 від 08 жовтня 2019 року. URL: https://mon.gov.ua/ua/ npa/pro-zatverdzhennya-tipovih-osvitnih-programdlya-1-2-klasiv-zakladiv-zagalnoyi-serednoyi-osviti.

5. Комлягіна В.Д. Соціалізація особистості на основі реалізації інтегрованих змістових міній програм 3 англійської мови. URL: https://www.narodnaosvita. kiev.ua/?page_id=6058

6. Нова українська шкома: основи Стандарту освіти. Аьвів, 2016. 64 с.

7. Скворцова С.О. Нормативна складова методичної компетентності майбутнього вчителя в галузі викладання математики. Вісник Чернігівського наиіонального педагогічного університету. Педагогічні науки. 2013. Вип. 110. С. 286-288.

8. Моїсеєв С.О., Гузар В.М., Шалар О.Г. Концептуамьні засади розвитку предметних компетентностей учнів 1-4 класів на уроках фізичної культури в Новій українській шкомі. Педагогічний альманах: збірник наукових праць [КВНЗ "Херсонська академія неперервної освіти"]. 2019. Вип.43. С. 45-56.

9. Методичні рекомендації щодо викладання навчамьних предметів у закладах загальної середньої освіти у 2019/2020 навчальному році: Додаток до миста МОН України від 01.07.2019 № 1/11-5966. Початкова школа. Учитель початкової школи. 2019. № 8 (вкиадка). С. 1-12.

10. Аюбченко О.М. Наскрізні мінії в освіті та їх реалізація на уроках ангмійської мови. Англійсъка мова ma rimepamypa. 2018. №24(574). URL: https: / /gymnasiya2.org.ua/doc/metod.pdf.

\section{References}

1. On approval of the State standard of basic and complete general secondary education: Resolution of the Cabinet of Ministers of Ukraine (2011) №1392 of November 23. Retrieved from https://osvita.ua/ legislation/Ser_osv / 28030/.

2. On approval of the State standard of primary education: resolution of the Cabinet of Ministers of
Ukraine (2018) № 87 of February 21. Retrieved from https://osvita.ua/legislation/Ser_osv/59891/.

3. Regarding methodical recommendations on teaching subjects in general secondary education institutions in the 2019/2020 academic year: letter of the Ministry of Education and Science of Ukraine (2019) № 1/11-5966 dated 01.07.2019. Retrieved from https://osvita.ua/legislation/Ser_osv/65024/.

4. About the statement of standard educational programs for 1-2 classes. institutions of general secondary education: order of the Ministry of Education and Science of Ukraine (2019) №1272 of October 8. Retrieved from https://mon.gov.ua/ua /npa/pro-zatverdzhennya-tipovih-osvitnih-programdlya-1-2-klasiv-zakladiv-zagalnoyi-serednoyi-osviti.

5. Komlyagina, V.D. Socialization of personality on the basis of the implementation of integrated content lines of programs in English. Retrieved from https://www.narodnaosvita.kiev.ua/?page_id $=6058$

6. New Ukrainian school: basics of the Education Standard (2016). Lviv. 64 p.

7. Skvortsova, S.O. (2013) Normative component of methodical competence of the future teacher in the field of teaching mathematics. Visnyk of Chernihiv National Pedagogical University. Pedagogical sciences, 110: $286-288$.

8. Moiseev, S.O. (2019). Conceptual principles of development of subject competencies of students of grades 1-4 in physical education lessons in the New Ukrainian school. Pedagogical almanac: collection of scientific works [MHEI "Kherson Academy of Conti?uing Education"], 43: 45-56.

9. Methodical recommendations for teaching subjects in general secondary education institutions in the 2019/2020 academic year.(2019): Appendix to the letter of the Ministry of Education and Science of Ukraine dated July 1, 2019 № 1/11-5966. Primary school teacher, 8(tab): 1-12.

10. Lyubchenko, O.M. (2018). Through lines in education and their implementation in English lessons. Retrieved from https://gymnasiya2.org. ua/doc/metod.pdf.

\section{KONDRATIEVA Alyona,}

PhD in Philosophy, Associate Professor of Preschool and Primary Education Department,

MIHE "Dnipro Academy of Continuing Education" of Dnipropetrovsk Regional Council

\section{CROSS-CUTTING CONTENT LINES IN PRIMARY SCHOOL}

Summary. Introduction. The article considers the essence of the competence approach to teaching primary school students. The article highlights the views of wellknown Ukrainian scholars on the modern terminological field of a competent approach to teaching pupils general secondary educational institutions. It is established that under the competence approach in education it is advisable to understand the orientation of the educational process to the formation hierarchically subordinated system of key, general subject and subject competences in pupils.

The publication presents the structural-functional relationship between the cross-cutting content lines, key, subject competences and their cross-cutting skills in implementing a competent approach to teaching primary pupils in New Ukrainian School.

The priority of the development of subject competences in the implementation of the competence approach to teaching primary pupils is shown.

It is concluded that the purpose of primary education in modern conditions is the comprehensive development of the child's personality in accordance with its age and individual psychophysiological characteristics and cogni- tive needs, the formation of cultural and moral and ethical values, mastery of key and subject competencies and cross-cutting skills, necessary life and social skills. to life in a democratic and information society and continuing education in primary school. Achieving this goal are crosscutting content lines in primary school, which involve the development of children of junior classes socially significant cross-curricular topics that contribute to the formation of their notions of society as a whole, develop the ability to apply knowledge in practice. Cross-cutting content lines are an effective means of integrating basic and general subject competencies, subjects and subject cycles in primary education.

Keywords: New Ukrainian school; communicative learning; personality-oriented learning socialization of personality; primary education; training; student; curriculum; cross-cutting content lines; subject competencies; competencies; training of primary school students.

Одержано редакиією 27.04.2020 Прийнято до публікаuї̈ 18.05.2020 